\title{
MANAJEMEN BERBASIS SEKOLAH
}

\author{
Oleh: Hamid
}

\begin{abstract}
Abstrak:
Sejak tahun 1998 sampai sekarang, era reformasi telah membawa perubahan mendasar dalam berbagai segi kehidupan berbangsa dan bernegara di Indonesia termasuk dalam bidang pendidikan. Salah satu perubahan mendasar yang terjadi dewasa ini adalah perubahan pada manajemen negara/pemerintahan, yaitu dari manajemen berbasis pusat menjadi manajemen berbasis daerah. Karena tulisan ini hanya berdasarkan tinjauan pustaka atau literature, maka untuk mengetahui dampak dari pelaksanaan pelaksanaan MBS terhadap proses belajar mengajar di sekolah, akan dikaji dan diulas berdasarkan fakta dan pendapat dari para pakar yang berkompeten dalam bidang pendidikan.
\end{abstract}

Kata Kunci: Manajemen, Berbasis Sekolah

\section{Pendahuluan}

A. Rasional

Sejak tahun 1998 sampai sekarang, era reformasi telah membawa perubahan mendasar dalam berbagai segi kehidupan berbangsa dan bernegara di Indonesia termasuk dalam bidang pendidikan. Salah satu perubahan mendasar yang terjadi dewasa ini adalah perubahan pada manajemen negara/pemerintahan, yaitu dari manajemen berbasis pusat menjadi manajemen berbasis daerah.

Secara resmi, perubahan manajemen ini telah diatur dalam Undang-Undang Republik Indonesia Nomor 22 Tahun 1999 yang disempurnakan dengan Undang-Undang RI Nomor 32 Tahun 2004 tentang Pemerintah Daerah dan Undang-Undang RI Nomor 33 Tahun 2004 tentang Perimbangan Keuangan Antara Pemerintah Pusat dan Pemerintah Daerah. Konsekwensi logis dari kedua Undang-Undang tersebut adalah bahwa manajemen pendidikan harus disesuaikan dengan jiwa dan semangat otonomi. Karena itu, manajemen pendidikan berbasis pusat diubah menjadi manajemen berbasis sekolah (MBS). 
MBS perlu diterapkan karena di lapangan ditemukan kenyataan-kenyataan sebagai berikut:

1) Manajemen berbasis pusat memiliki banyak kelemahan.

2) Sekolah paling memahami permasalahannya.

3) Perubahan akan terjadi jika semua warga sekolah berpartisipasi dalam merencanakan dan merumuskan kebijakan sekolah.

4) Telah lama pengaturan yang bersifat birokratik lebih dominan daripada tanggungjawab profesional. (PH, Slamet, 2000)

Salah satu komponen atau bagian terpenting dari institusi sekolah adalah siswa itu sendiri. Mendisiplinkan siswa adalah suatu pekerjaan yang tidak mudah karena berkaitan dengan harkat dan martabat manusia. Padahal faktor kedisiplinan sangatlah penting dalam berlangsungnya proses belajar mengajar yang lebih efektif. Bertolak dari hal tersebut maka pihak sekolah dengan kewenangan yang dipunyainya membuat suatu aturan yang mengatur tentang kedisiplinan siswanya yang berorientasi kepada sistem angka kredit prestasi dan pelanggaran. Tentunya aturan ini tidak akan bertentangan dengan aturan atau norma yang berlaku di negara kita ini.

\section{B. Permasalahan}

Berdasarkan uraian di atas maka dapatlah dirumuskan suatu permasalahan yang diungkapkan dalam tulisan ini yaitu: Bagaimana dampak pelaksanaan manajemen berbasis sekolah (MBS) terhadap proses belajar mengajar di sekolah."

\section{Batasan Masalah}

Karena tulisan ini hanya berdasarkan tinjauan pustaka atau literature, maka untuk mengetahui dampak dari pelaksanaan pelaksanaan MBS terhadap proses belajar mengajar di sekolah, akan dikaji dan diulas berdasarkan fakta dan pendapat dari para pakar yang berkompeten dalam bidang pendidikan.

\section{Pembahasan}

A. Pengertian Manajemen Berbasis Sekolah (MBS) 
Dampak dari pelaksanaan Undang-Undang RI Nomor 32 Tahun 2004 dan Undang-Undang RI Nomor 33 Tahun 2004 adalah pemerintah daerah diberi hak, wewenang, dan kewajiban untuk mengatur dan mengurus sendiri urusan pemerintahan dan kepentingan masyarakat setempat sesuai dengan peraturan perundang-undangan yang berlaku. Yang menjadi kewenangan pemerintahan daerah (kabupaten/kota) berdasarkan Pasal 14 Undang-Undang RI Nomor 32 Tahun 2004 sebagai berikut :

1) Perencanaan dan pengendalian pembangunan.

2) Perencanaan, pemamfaatan, dan pengawasan tata ruang.

3) Penyelengaraan ketertiban umum \& ketenteraman masyarakat.

4) Penyediaan sarana dan prasarana umum.

5) Penanganan bidang kesehatan,

6) Penyelenggaraan pendidikan.

7) Penanggulanagan masalah sosial.

8) Pelayanan bidang ketenagakerjaan.

9) Fasilitasi pengembangan koperasi, usaha kecil dan menegah.

10) Pengendalian lingkungan hidup

11) Pelayanan pertanahan.

12) Pelayanan kependudukan, dan catatan sipil.

13) Pelayanan administrasi umum pemerintahan.

14) Pelayanan administrasi penanaman modal.

15) Penyelenggaraan pelayanan dasar lainnya.

16) Urusan wajib lainnya yang diamanatkan oleh peraturan perundang-undangan.

Konsekwensi logis dari pelaksanaan Undang-Undang Otonomi Daerah tersebut adalah perubahan terhadap manajemen pendidikan. Karena itu, manajemen pendidikan berbasis pusat diubah menjadi manajemen pendidikan berbasis sekolah (MBS). Selanjutnya pada Pasal 51 Undang-Undang RI Nomor 20 tahun 2003 tentang Sistem Pendidikan Nasional dijelaskan bahwa pengelolaan satuan pendidikan anak usia dini, pendidikan dasar, dan pendidikan menengah dilaksanakan berdasarkan standar pelayanan minimal dengan prinsip manajemen berbasis sekolah/madrasah. 
Istilah MBS seringkali didengar dari perbincangan orangorang di sekitar kita, namun masih banyak orang yang belum memahami istilah tersebut. Para pakar pendidikan telah banyak memberikan kajian dan ulasan terhadap istilah tersebut. Slamet PH,(2000), mengemukakan bahwa istilah MBS berasal dari tiga kata yaitu manajemen, berbasis, dan sekolah.

Manajemen adalah pengkoordinasian dan penyerasian sumber daya melalui sejumlah input manajemen untuk mencapai tujuan atau untuk memenuhi kebutuhan pelanggan. Berbasis berarti "berdasarkan pada" atau "berfokuskan pada". Sekolah adalah suatu organisasi terbawah dalam jajaran Departemen Pendidikan Nasional (Depdiknas) yang bertugas memberikan "bekal kemampuan dasar" kepada peserta didik atas dasar ketentuanketentuan yang bersifat legalistik dan profesionalistik.

Berdasarkan uraian di atas, dapat disimpulkan bahwa "manajemen berbasis sekolah" adalah pengkoordinasian dan penyerasian sumber daya yang dilakukan secara otonomis oleh sekolah melalui sejumlah input manajemen untuk mencapai tujuan sekolah dalam bingkai pendidikan nasional, dengan melibatkan semua kelompok kepentingan yang terkait dengan sekolah secara langsung dalam proses pengambilan keputusan (partisipatif).

\section{B. Tujuan Manajemen Berbasis Sekolah (MBS)}

Tujuan pelaksanaan MBS adalah untuk memberdayakan sekolah, terutama sumber daya manusianya (kepala sekolah, guru, karyawan, siswa, orang tua, dan masyarakat sekitarnya), melalui pemberian kewenangan, fleksibilitas, dan sumber daya lain untuk memecahkan persoalan yang dihadapi oleh sekolah yang bersangkutan.

Ciri-ciri sekolah yang "berdaya" adalah:

1) Tingkat kemandirian tinggi

2) Tingkat ketergantungan rendah

3) Bersifat adaptif, antisipatif dan proaktif

4) Memiliki jiwa kewirausahaan tinggi

5) Bertanggungjawab terhadap hasil sekolah 
6) Memiliki kontrol yang kuat terhadap input manajemen dan sumber dayanya

7) Kontrol terhadap kondisi kerja

8) Komitmen yang tinggi pada dirinya

9) Dinilai oleh pencapaian prestasinya.

Selanjutnya, ciri-ciri sumber daya manusia (SDM) sekolah yang berdaya antara lain:

1) Pekerjaan adalah miliknya

2) Dia bertanggungjawab

3) Dia memiliki suara bagaimana sesuatu dikerjakan

4) Pekerjaannya memiliki konstribusi

5) Dia tahu posisinya dimana

6) Dia memiliki kontrol terhadap pekerjaannya

7) Pekerjaannya merupakan bagian hidupnya

Tujuan utama MBS adalah untuk meningkatkan mutu pendidikan. Dengan adanya MBS, sekolah dan masyarakat tidak perlu lagi menunggu perintah dari pusat/atas. Mereka dapat mengembangkan suatu visi pendidikan yang sesuai dengan keadaan setempat dan melaksanakan visi tersebut secara mandiri.

\section{Perubahan Pendekatan Manajemen Pendidikan}

Sejalan dengan pemberlakuan undang-undang otonomi daerah, maka Depdiknas telah melakukan penyesuaianpenyesuaian terhadap pendekatan manajemen pendidikan yaitu dari manajemen berbasis pusat menuju manajemen berbasis sekolah , seperti yang tercantum pada tabel berikut:

\begin{tabular}{|c|c|c|}
\hline $\begin{array}{c}\text { Manajemen Berbasis } \\
\text { Pusat }\end{array}$ & Menuju & Manajemen Berbasis Sekolah \\
\hline Sub-ordinasi & & Otonomi \\
\hline Pengambilan keputusan & & Pengambilan keputusan \\
\hline Terpusat & & Partisipatif \\
\hline Ruang gerak kaku & & Ruang gerak luwes \\
\hline Pendekatan birokratik & & Pendekatan profesionalisme \\
\hline Sentralistik & & Desentralistik \\
\hline Diatur & & Motivasi diri \\
\hline Overregulasi & & Deregulasi \\
\hline Mengontrol & & Mempengaruhi \\
\hline
\end{tabular}




\begin{tabular}{|c|c|}
\hline Mengarahkan & Memfasilitasi \\
\hline Menghindari resiko & Mengolah resiko \\
\hline Gunakan uang semuanya & $\begin{array}{c}\text { Gunakan uang seefisien } \\
\text { mungkin }\end{array}$ \\
\hline Individual cerdas & Teamwork kompak \& cerdas \\
\hline Informasi terpribadi & Informasi terbagi \\
\hline Pendelegasian & Pemberdayaan \\
\hline Organisasi herarkis & Organisasi datar \\
\hline
\end{tabular}

Sumber : Slamet PH, 2000

D. Karakteristik Manajemen Berbasis Sekolah (MBS)

Manajemen berbasis sekolah memiliki karakteristik yang perlu dipahami oleh sekolah yang akan menerapkannya. Dengan kata lain, jika sekolah ingin berhasil dalam menerapkan MBS, maka beberapa karakteristik MBS perlu dipelajari dan dipahami dengan baik. Membahas karakteristik MBS tidak dapat dipisahkan dengan karakteristik sekolah efektif. Jika MBS dianggap sebagai wadah/kerangkanya maka sekolah efektif merupakan isinya. Oleh sebab itu, karkteristik MBS memuat elemen-elemen sekolah efektif yang dikategorikan menjadi input, proses dan output.

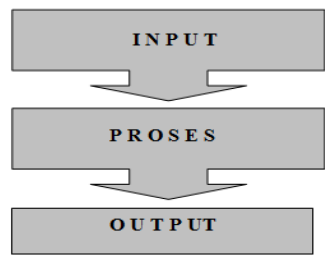

Gambar 1. Karakteristik Manajemen Berbasis Sekolah (MBS)

Input pendidikan adalah segala sesuatu yang harus tersedia karena dibutuhkan untuk berlangsungnya suatu proses. Sesuatu yang dimaksud berupa sumberdaya dan perangkat lunak serta harapan-harapan sebagai pemandu berlangsungnya proses. Input sumberdaya meliputi sumberdaya manusia (kepala sekolah, guru, konselor, karyawan, peserta didik) dan sumberdaya selebihnya (peralatan, perlengkapan, uang, bahan,dsb).

Adapun input-input pendidikan antara lain:

1) Memiliki kebijakan, visi, misi, tujuan, sasaran mutu yang jelas. 
2) Sumberdaya tersedia dan siap.

3) Staf yang kompeten dan berdedikasi tinggi.

4) Memiliki harapan prestasi yang tinggi.

5) Fokus pada pelanggan (khususnya siswa).

6) Input manajemen (tugas, rencana, program, ketentuanketentuan, pengendalian/pengawasan).

Proses merupakan berubahnya "sesuatu" menjadi "sesuatu yang lain". Sesuatu yang berpengaruh terhadap berlangsungnya proses disebut input, sedangkan sesuatu dari hasil proses disebut output. Pada penyelenggaraan pendidikan di sekolah-sekolah, yang dimaksud dengan proses pendidikan meliputi empat hal yaitu :

1) Proses pengambilan keputusan.

2) Proses pengelolaan kelembagaan.

3) Proses pengelolaan program.

4) Proses belajar mengajar.

Output pendidikan adalah prestasi sekolah yang dihasilkan oleh proses pembelajaran dan manajemen. Output sekolah dapat diukur dengan kinerja sekolah yang terdiri dari: (1) Efeketifitas; (2) Kualitas; (3) Produktivitas; (4) Efisiensi; (5) Inovasi; (6) Kualitas kehidupan kerja; dan (7) Moral kerja.

\section{E. Strategi Implementasi Manajemen Berbasis Sekolah (MBS)}

Hakekatnya, mengubah pendekatan manajemen berbasis pusat menjadi MBS bukanlah pekerjaan mudah, tetapi merupakan suatu proses yang terus-menerus dan melibatkan seluruh elemen yang bertanggungjawab dalam penyelenggaraan pendidikan di sekolah.

Strategi utama yang digunakan dalam mengimplementasikan manajemen berbasis sekolah, adalah :

1) Mensosialisasikan konsep MBS kesemua warga sekolah.

2) Melaksanakan analisis situasi sekolah dan luar sekolah yang hasilnya berupa tantangan nyata yang harus dihadapi sekolah dalam mengubah manajemen berbasis pusat menjadi MBS.

3) Merumuskan tujuan situasional yang akan dicapai dari pelaksanaan manajemen berbasis sekolah berdasarkan tantangan yang dihadapi. 
4) Mengidentifikasi yang perlu dilibatkan untuk mencapai tujuan situasional dan masih perlu diteliti tingkat kesiapannya.

5) Menentukan tingkat kesiapan setiap fungsi dan faktorfaktornya malalui analisis SWOT (Strength, Weakness, Opportunity, and Threat).

6) Memilih langkah-langkah pemecahan masalah.

7) Membuat rencana jangka pendek, menengah dan panjang beserta program-programnya.

8) Melaksanakan program-program untuk merealisasikan rencana jangka pendek MBS.

9) Pemantauan terhadap proses dan evaluasi terhadap hasil MBS.

F. Dampak MBS Terhadap Peningkatan Mutu Pendidikan

Tujuan MBS adalah peningkatan mutu pembelajaran atau pendidikan. Program MBS ini terdiri atas tiga komponen yaitu:

1) Manajemen Berbasis Sekolah (MBS)

2) Peran Serta Masyarakat (PSM)

3) Peningkatan Mutu KBM melalui Peningkatan Mutu Pembelajaran (PAKEM).

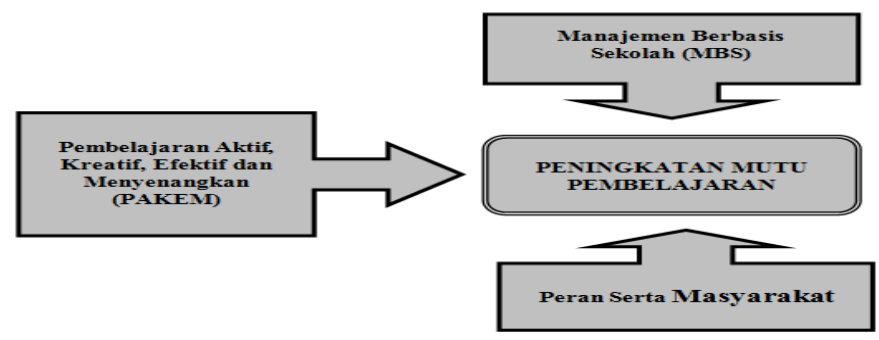

Gambar 2. Peningkatan Mutu KBM melalui Peningkatan Mutu Pembelajaran (PAKEM)

Untuk merealisasikan program MBS maka perlu dilakukakan kegiatan-kegiatan sebagai berikut:

1) Pelatihan kepala sekolah, guru dan masyarakat/komite sekolah.

2) Penyusunan Rencana Induk Pengembangan Sekolah (RIPS).

3) Penyusunan Rencana Anggaran Pendapatan dan Belanja Sekolah (RAPBS). 
Program MBS di sekolah-sekolah tidaklah mungkin terwujud dan berhasil jika tidak ditunjang oleh biaya operasional sekolah yang cukup sehingga rencana yang telah dibuat oleh sekolah dan masyarakat dapat dilaksanakan dengan baik. Saat ini biaya operasional sekolah yang berasal dari APBD/Pemerintah masih minim dan baru diprioritaskan bagi jenjang pendidikan tingkat SD dan SMP. Sedangkan untuk jenjang pendidikan tingkat SMA/SMK lebih banyak menerima biaya operasional dari Komite Sekolah.

Untuk itu, diharapkan jumlah dana operasional dari APBD/Pemerintah di tahun-tahun mendatang agar lebih ditingkatkan sesuai dengan amanat Undang-Undang RI Nomor 20 Tahun 2003 tentang Sisdiknas pasal 49 ayat 1 yang menyatakan: " Dana pendidikan selain gaji pendidik dan biaya pendidikan kedinasan dialokasikan dana minimal $20 \%$ dari APBN pada sektor pendidikan dan minimal $20 \%$ dari APBD".

Dari uraian diatas dapatlah dirangkum mengenai dampak atau pengaruh MBS terhadap sekolah dalam rangka peningkatan mutu pendidikan antara lain:

1) MBS menciptakan rasa tanggungjawab yang tinggi bagi warga sekolah melalui manajemen sekolah yg lebih terbuka.

2) Sifat keterbukan MBS meningkatkan kepercayaan, motivasi, serta dukungan orang tua dan masyarakat terhadap sekolah.

3) Pelaksanaan Pembelajaran Aktif, Kreatif, Efektif dan Menyenangkan (PAKEM) akan meningkatkan prosentasi kehadiran siswa di sekolah karena mereka merasa senang dan nyaman belajar.

4) Dukungan biaya operasional yang memadai akan menunjang terlaksananya program-program yang telah disusun bersama antara pihak sekolah dan masyarakat.

\section{Penutup}

A. Kesimpulan

Menyimak uraian pada poin 1 dan poin 2 dari tulisan ini, maka dapat ditarik kesimpulan sebagai jawaban dari permasalahan antara lain: 
1) Penerapan MBS di sekolah-sekolah adalah merupakan konsekwensi dari pelaksanaan Undang-Undang Otonomi Daerah Nomor 32 Tahun 2004 dan Undang-Undang Sisdiknas Nomor 20 Tahun 2003.

2) Jika MBS dilaksanakan dengan baik dan terbuka maka mutu pendidikan di sekolah-sekolah akan lebih baik dan meningkat.

3) MBS hanya dapat dilaksanakan apabila semua warga sekolah mempunyai rasa komitmen dan tanggung jawab tinggi terhadap peningkatan mutu pendidikan di sekolahnya masing-masing.

B. Saran

1) Agar pemerintah pusat dan pemerintah daerah betul-betul komitmen terhadap terealisasi anggaran pendidikan sebesar 20 $\%$ dari anggaran APBN dan APBD sehingga tersedia sarana dan prasarana sekolah yang memadai.

2) Peningkatan SDM melalui pelatihan terhadap kepala sekolah, guru dan tenaga administrasi lainnya di sekolah-sekolah sehingga pelaksanaan MBS dapat berjalan efektif dan baik.

\section{Daftar Kepustakaan}

Direktorat Dikmenum, 2000. Manajemen Peningkatan Mutu Berbasis Sekolah, Jakarta: Depdiknas.

MBE Project On Line, 2008. Manajemen Berbasis Sekolah, diakses dari http://mbeproject.net/mbs. pada tanggal 27 Januari 2008.

PH, Slamet., 2000. Menuju Pengelolaan Pendidikan Berbasis Sekolah. Makalah, disampaikan dalam Seminar Regional dengan Tema " Otonomi Pendidikan dan Implementasinya dalam EBTANAS" pada Tanggal 8 Mei 2000 di Universitas Panca Marga Probolinggo, Jawa Timur.

Undang-Undang RI Nomor 20 Tahun 2003 tentang Sistem Pendidikan Nasional (Sisdiknas). Jakarta : Fokusmedia

Undang-Undang RI Nomor 32 Tahun 2004 tentang Pemerintahan Daerah. Jakarta : Fokusmedia. 